\title{
INNOVATION AS A FACTOR OF THE SOCIO-ECONOMIC EFFICIENCY OF TAX CONSULTING
}

\author{
Olga Marchenko', Nataliia Maryniv², Olga Yarmak ${ }^{3}$
}

\begin{abstract}
The aim of the article is to study the theoretical and methodological principles of the interconnection and interdependence of innovation and the socio-economic efficiency of tax consulting and on this basis to determine the areas and tasks of innovation management in this sphere. The subject of the study is innovation and innovative tax consulting services. Methodology. The research is based on the use of general scientific and special-scientific methods and techniques of scientific knowledge. The systematic approach enabled to reveal the content of the social and economic efficiency of tax consulting as the integrity of its economic performance as a practical legal activity based on enterprise and a structural unit of the national economy and socio-economic effects of its functioning as an institution of legal economy and the rule of law. The method of functional analysis enabled to substantiate the author's approach to the definition of infrastructural and imputed functions of the tax-consulting institute, to reveal the content of its innovative function, its internal and external components. Based on a categorical analysis of innovations in the legal sphere, the concept of innovations and innovative services of tax consulting is considered to reveal a combination of legal, economic, social, and innovative characteristics in its content. The methodology of facet classification enabled to determine and characterize types of innovations in tax consulting, such as product, process, management-organizational, social innovations, as well as to ground areas and measures of management of innovative activity in this sphere of practical legal activity. The results of the study revealed that the social and economic efficiency of tax consulting as a unity of its economic performance and socio-economic effects are closely interconnected with its innovation, because innovations as certain changes in the product, technology, service provision, consulting, and market activity are efficiency factor, while possibilities of their implementation depend on the economic results of entrepreneurial activity in legal assistance on taxation and the quality of management of innovation activity. Practical implications. In the research, the classification of tax consulting innovations enabled to reveal the areas and management measures of innovation development in this practical legal activity to ensure its efficiency as a type of entrepreneurial activity and socio-economic institute, consisting of updating the product portfolio by developing and providing bundled, boutique services, development of niche industries; tax consulting on-line and automation of typical professional services; use of legal crowdsourcing and crowdfunding; introduction of the model of open innovation; management of innovative knowledge; formation of external and internal tax consulting networks; pro bono services. Relevance/originality. The proposed author's approach to the definition of the socio-economic efficiency and the innovative function of tax consulting, their interconnection and interdependence is the theoretical basis for, first, studies of socio-economic and legal conditions and factors of effective legal assistance on taxation on an innovative foundation, and second, development of activities for the innovative improvement of tax consulting, and effective realization of its functions.
\end{abstract}

Key words: tax consulting, social and economic efficiency of tax consulting, innovative function of tax consulting, innovations and innovative services of tax consulting, management of innovative activity of tax consulting subjects.

JEL Classification: E62, K34, L80, M21, O31

\section{General problem statement}

Under the current development of the legal economy, implementation of systemic socio-economic reforms, development of international economic relations, globalization and European integration, the role of tax consulting in providing economic entities with professional knowledge and information on tax planning and reporting, optimizing the tax burden in accordance with the requirements of the current legislation is of particular importance. This requires

\footnotetext{
Corresponding author:

${ }^{1}$ Yaroslav Mudryi National Law University, Ukraine.

${ }^{2}$ Yaroslav Mudryi National Law University, Ukraine.

${ }^{3}$ Kharkiv Institute of Finance of Kyiv National University of Trade and Economics, Ukraine.
} 
a significant increase in the socio-economic efficiency of tax consulting based on innovation.

\section{Literature review}

Nowadays, the practice of tax consulting demonstrates many concrete examples of innovations in this sphere, which requires their analysis, generalization and, accordingly, systematization of knowledge on the conditions, factors, and areas of innovative provision of the socio-economic efficiency of professional legal assistance to economic entities on taxation issues. The economy and law experts emphasize the importance of the analysis and practice of legal (Shevchenko, 2017; Khokhuliak, 2016; Miroshnykov; Foremnyi, 2017; Yurydychni startapy na rynku yurposluh; Bot-providnyk), which is a significant stage in the scientific research, but not sufficient to reveal the role of innovation in socio-economic efficiency of tax consulting as entrepreneurship and the institute of legal economy.

\section{Unsettled issues of a general problem}

The important interconnected components of the problem of innovative factors of the tax consulting effectiveness are: 1) interpretation of the content of social and economic efficiency of tax consulting and its innovative function, substantiation of their interconnection and interdependence; 2) definition of innovation types and innovation areas in professional assistance on taxation, theoretical substantiation of the content of "innovation of tax consulting," "innovative services of tax consulting"; 3) justification of management areas of innovative activity in tax consulting to ensure its socio-economic efficiency.

The aim of the article is to justify the content and types of innovation and innovative services of tax consulting as factors of its socio-economic efficiency and on this basis to determine the areas and measures of management of innovation activity in professional assistance on taxation.

\section{The main material}

Tax consulting, as a provision of professional assistance to businesses and the population on taxation, is: first, an important component of many business services, such as audit, management consulting, legal and accounting business services, etc.; second, legal practice, that is, a certain type of practical legal activity; third, the entrepreneurial activity of lawyers and their organizations in providing professional tax services to achieve a certain legal result and profit; fourth, the socio-economic institute, a component of the legal economy. Therefore, the content of the socio-economic efficiency of legal consulting is multidimensional with economic, legal, and social characteristics, hence it should be defined systematically to reflect, first, the dual nature of tax consulting as a business aimed at profit, and professional practice of lawyers, aimed at achieving a certain legal result; second, its social role as a formation and development factor of a law-governed state and legal economy. Based on the systematic approach to determining the social and economic efficiency of tax consulting, the following components should be included in the content of this category:

- economic efficiency of tax consulting as a type of business activity and a structural unit of the national economy;

- socio-economic effects of tax consulting, connected with its functions, in other words, the main areas of implementation of its claimed purpose (social role) as a socio-economic institute, which at the microeconomic level is a support in achieving the goals of individuals and legal entities in the legal sphere by providing them with legal assistance; at the macroeconomic level, is in ensuring and protecting law and order in all spheres of human activity. The system of tax-consulting functions includes: - its functions, which reveal its content as a professional activity of lawyers to provide business entities and the population with the necessary legal knowledge and information, that is, functions of accumulation and retransmission;

- infrastructure function for minimizing customer market transaction costs;

- imputed (assigned) functions: implementation of legal, rationalizing, innovative, regulating functions.

Socio-economic effects of tax consulting characterize its impact on the development of the rule of law and the legal economy due to the development and nature of its functions.

Economic effectiveness and socio-economic effects of tax consulting depend on its innovation. An innovative function is inherent in tax consulting, that is, internal (development and introduction of innovations and innovative services in legal assistance on taxation issues); and external, that is promoting the innovative activity of business entities in the legal space, legal protection of innovations and innovators. It should be emphasized that the internal and external components of the innovative function of tax consulting are interdependent and interrelated and determine its innovation as the ability to innovate and innovation as a certain level of perception of innovations by the subjects of tax consulting. Nowadays, the innovative function of tax consulting becomes the main factor of the socio-economic efficiency of its subjects. Practical implementation of the innovative function contributes to not only legal but also socio-economic outcomes of lawyers and customers of tax-consulting services, as well as society as a whole.

It is important to distinguish between the concept of legal novelty (a novelty in law), legal innovation, tax- 
consulting innovation, innovative legal services, and innovative tax-consulting services. In legal science, the term "legal novelty" is defined as: 1) improvement of regulatory documents as the result of legislative activity, such as new laws and articles in the current laws, amendments and changes made to regulations, etc.; 2) certain legal actions. Therefore, legal novelty is a purely legal category. It should be emphasized that novelties in law are implemented in the practice of tax consulting as an entrepreneurial activity in providing legal assistance via the market.

In the content of legal innovations as legal novelties introduced into practical legal activity and the changes caused by them in the legal space and legal practice, the purely legal and market characteristics of legal consulting are combined. According to L.S. Shevchenko's classification, legal innovations include: 1) new legal knowledge as an intellectual product of scientific research, introduced to the market of legal services; 2) new or improved technologies for providing legal services; 3 ) formation of new legal services and practices (Shevchenko, 2017).

Innovations in tax consulting are the introduction of new ideas, intelligent products, advisory technologies on taxation and the entrepreneurial activities of its subjects. Innovative tax consulting services are new or improved professional actions of lawyers to provide individuals and legal entities with legal assistance on taxation issues to achieve the legal result and ensure the satisfaction of the needs and benefits of consulting process participant. The content of these concepts combines the legal, economic, social, and innovative characteristics of tax consulting.

The development and effectiveness of innovative activities of tax consultants depend on the quality of management, improvement of which is an important condition and a factor in their socio-economic efficiency. Determination of the main areas of innovative activity management in tax consulting is based on the classification and characterization of innovation types, such as: product innovations (new services and practices of tax consulting); process innovations concerning the technologies, methods, and techniques of practical legal activity of tax advisers; organizational and managerial innovations (new organizational forms of tax consultors, managerial and social innovations.

1. Product innovations in tax consulting. The task of innovation management in tax consulting is the timely identification of possible changes in the market for legal services and the implementation of activities to preserve and strengthen competitive positions based on product innovations. Nowadays, product innovations in tax consulting are: 1) integrated (bundled) professional services involving knowledge and experience of specialists in various branches of law, economists, financiers, accountants, psychologists, and other professionals; 2 ) individualized (boutique) professional services that are non-standard and not replicated; 3) transformer services adapted to the requirements and specifics of the various tax consulting industry; 4) niche industry of tax consulting, the introduction of which is caused by a change in the structure of demand for services in taxation in a particular economic activity. For example, the development of start-ups in various economic sectors leads to the demand for their support by tax professionals forming a new segment (niche) of tax consulting.

2. Process innovations in tax consulting. An important area of the innovative management of tax consulting is the development of on-line counselling and the automation of typical professional services. In Ukraine, a legal online platform BITLEX, a resource Freelawyer.ua, have already been created to find a lawyer for litigation or for consultation (Bot-providnyk). According to Yaremenko, these online services do not provide advisory or other legal services, but they have contracts of work/partnerships with law firms or are on-line platforms for freelance lawyers. Such services are nothing more than another modern channel for selling legal services (Yaremenko, 2016). It should be emphasized that on-line counselling is carried out by lawyers and law firms that develop this area of tax consulting; therefore, this technology does not lead to the depersonalization of services and the replacement of lawyers with legal bots. Unlike on-line services, the automation of tax-consulting services, based on the programs that replace lawyers, allows solving certain legal issues without the participation of lawyers. For example, for introducing innovative Legal Tech projects, software is created to analyse and prepare legal documents without the assistance of professional lawyers, as well as to almost automate the decision-making process on legal issues, to make contracts, wills and other documents (Miroshnykov). An example of such technologies is the DoNotPay bot-lawyer created by Joshua Broder now launching an updated version of the program to help people with small legal issues. Since 2016, the project has helped to challenge hundreds of thousands of fines for parking for 7 million pounds. After updating, the botlawyer will be able to conduct other operations in various fields of law (Krasilnikova, 2017).

The introduction of these technologies facilitates access to justice for the general population that leads to the formation of new segments of tax consulting. In 2015, a joint study by the Hague Institute of Innovation in Law and the Kharkiv Institute of Sociology revealed the problem of access to justice for the population in Ukraine, according to the following data that more than half of Ukrainians have faced this problem over 5 years, $59 \%$ of Ukrainians have never even sought advice from lawyers and lawyers, and only 5\% of Ukrainians are ready to solve their problems by suing out (Haazkyi instytut innovatsii u pravi provede konkurs sered yurydychnykh startapiv... ). According to E. Miroshnykov, these projects help ordinary citizens reduce legal service costs and gain 
wider access to justice (Miroshnykov). Consequently, these technologies have signs of not only procedural but also social innovations in legal consulting.

The new area of tax-consulting innovation management is the management of legal crowdsourcing (technology for the search, selection, mobilization, transfer and use of legal knowledge in electronic communities). Legal crowdsourcing covers the following areas: obtaining legal knowledge and information through the Internet; custodianship as an involvement in solving certain legal problems of many participants of the professional electronic communities that do not have territorial, geographical, corporate or other restrictions; provision and promotion of legal services and their creators through the Internet. The management of legal crowdsourcing covers such forms as: 1) internal legal crowdsourcing, that is, the exchange of legal knowledge and information within the firm. This form of crowdsourcing is appropriate, in case of, first, the divisions of the law firm are territorially separated from each other, and second, a remote work on the Internet as an employment pattern of a lawyer; 2) partner legal crowdsourcing, that is, intellectual cooperation of lawyers of different firms for the exchange of legal knowledge and information; 3) external legal crowdsourcing as an involvement of knowledge of the participants of electronic communities in solving a certain legal problem; 4) legal crowdsourcing, used by law firms, government agencies. The application of legal crowdsourcing increases the ability of tax consulting companies to involve knowledge and information resources and increase the effectiveness of consultancy.

3. Managerial and organizational innovations in tax consulting. First, an important component of the management of tax-consulting innovations is the choice and implementation of the organizational pattern of the innovation process. In the pattern of closed innovations, the law firm independently, at its own expense and risks, carries out all stages of the innovation process in confidentiality. Characterizing closed innovations $\mathrm{H}$. Chesbrough emphasizes the necessity of an independent discovery of $R \& D$, its improvement to the level of the product and getting results to profit from it (Chesbrough, 2007). The pattern of open innovation involves, first, certain stages of the innovation process carried out beyond the law firm by cooperating with independent researchers, scientists, specialists, innovators; and second, innovative products, created outside the firm, in the innovation process. Intellectual property should make a profit if other use it and intellectual property should be bought from other companies if it meets one's business pattern (Chesbrough, 2007). Implementation of the open innovation pattern increases the economic efficiency of tax consulting as a business significantly.

Second, innovation management is the management of knowledge necessary for innovation. The task of management of innovative knowledge of tax consulting is their involvement, storage, accumulation, protection, and effective use in the consulting process. The main objects of management of innovative knowledge are: 1) holders of new knowledge (lawyers and other professionals, whose intellectual activity is an intellectual product). It is the human capital of tax consulting innovations; 2) intellectual property objects that are a part of the intellectual capital of a law firm. This is a capital knowledge of tax consulting; 3 ) the knowledge base of tax consulting, can be formal (information accumulated on paper and electronic media, which is a generalization of collective knowledge about different areas of activity of its subjects); informal (corporate culture and corporate memory); 4) the movement (integration) of innovative knowledge covering their creation, involvement, transformation, accumulation, storage, exchange, and use. Knowledge management contributes to their transformation into the intellectual capital of tax consulting, the use of which ensures the growth of value, profit, and other benefits.

The organizational innovations in tax consulting are the application of a virtual law firm by creating its external and internal networks. The network principle is the basis for forming an innovative knowledge management and intellectual professional activity management system. The internal network is based on the group work of lawyers and other professionals, whose result is not the total individual contributions to solving the problem but a positive synergistic effect of integrating intellectual resources of tax consulting. The core of the external network is an intelligent network that includes providers of knowledge and information necessary for effective advisory activity. It consists of various information firms, agencies, clients, partners, state bodies, community organizations, professional associations of lawyers, educational institutions, mass media, etc. Construction of an intellectual network is important in increasing the efficiency of tax consulting.

Novelty in the management of innovative financing of tax consultants is the use of (Howe, 2012) (technology for involving a large number of people, such as Internet users, connected by network communities, to finance a variety of legal projects, start-ups, social innovations). Crowdfunding enables a law firm to not only involve the necessary funds for innovation but also minimize market transaction costs for these purposes.

4. Social innovation in legal consulting. The non-standard solution of social problems is the element of the content of social innovation (Boiko-Boichuk, 2009). Nowadays, the social innovation of legal consulting in general and tax consulting in particular are legal pro bono services, directly connected with the decision of problematic access of the population to justice, an effective implementation of social responsibility of legal business. Legal pro bono services are not paid by their consumers, and the expenses of lawyers for their provision are not compensated. 
It is legal assistance free of charge for the consumer and non-recompensable for lawyers. It is a wide range of professional lawyers' services that meet all the requirements and criteria of practical legal activity. In addition, although pro bono publico legal is carried out free of charge and without compensation for lawyers, this is not the charity of lawyers, but their systematic professional activity in providing legal assistance, the implementation of which is a criterion of professionalism and social responsibility of legal business entities. A. Nasadiuk emphasizes that the range of "true" pro bono is extremely broad: from legal counselling of individuals and organizations, legal support to workers in culture and sport in the lawmaking process, and analytical reports for international reviews (Nasadyuk, 2016). According to the Code of Professional Ethics of the American Bar Association, a specialist should devote at least 50 hours of pro bono publico legal services a year. Furthermore, a significant number of companies provide much more hours (Pro bono: sekret uspekha yuridicheskoi kompanii). In Ukraine, in 2015, 49\% of lawyers render legal pro bono services (Rabota ne pro bono). A socially responsible legal business is a factor for the implementation of this social innovation in legal practice.

\section{Conclusions and areas of further research}

The social and economic efficiency of tax consulting as a unity of its economic performance and socio- economic effects are interconnected with its innovation, because innovations are efficiency factor, while possibilities of their implementation depend on the economic results of entrepreneurial activity in legal assistance on taxation. The innovation of tax consulting, as certain changes in the product, technology, service provision, management of consulting and market activity of its subjects, is the object of innovation management in practical legal activity determining its content and main areas. Nowadays, the management of the innovative development of tax consulting involves the management of creation and introduction of new legal services, innovative technologies of legal activities, organizational and managerial innovations, social innovations that provide creators and consumers of legal services with a qualified legal assistance in taxation, competitiveness, and efficiency.

Further research is aimed at developing measures for improving the socio-economic efficiency of tax consulting on the basis of the innovative knowledge management and introduction of an innovation pattern to innovative activity to overcome financial, intellectual, and time constraints, optimization of transformation and transaction costs on innovation activities of subjects of tax consultancy by involving knowledge and activities of external independent participants in the innovation process and transferring some of their functions and separating units for certain stages of innovation.

\section{References:}

Shevchenko, L. S. (2017). Innovatsiinist yurydychnoho biznesu: kryterii ta chynnyky. [Innovativeness of the legal business: Criteria and factors]. Proceedings from International Scientific and Practical Conference on Formation and development of innovative potential of the Ukrainian economy, 2, 10-13. (in Ukrainian)

Khokhuliak, O. O. (2016). Tendentsii rozvytku meharehionalnykh rynkiv yurydychnykh posluh [Trends in the development of megaregional markets of legal services]. Naukovyi visnyk Mizhnarodnoho humanitarnoho universytetu. Seriia "Ekonomika i menedzhment", 16, 108-111. (in Ukrainian)

Miroshnykov, Ye. Legal Tech v Ukraini: innovatsii u yurysprudentsii [Legal Tech in Ukraine: Innovation in Law]. Retrieved from: http://yur-gazeta.com/publications/practice/inshe/legal-tech-v-ukrayini-innovaciyi-uyurisprudenciyi.html (accessed September 5, 2018) (in Ukrainian)

Foremnyi, D. (September 27, 2017). Legal + Tech = A2J? Yurydychna hazeta [Legal newspaper]. Retrieved from: http://yur-gazeta.com/publications/practice/inshe/legal--tech--a2j.html (accessed September 5, 2018) (in Ukrainian)

Yurydychni startapy na rynku yurposluh. Uyakykh sferakh servisy z nadannia yurposluh mozhut staty konkurentamy yurfirmam? [Legal startups on the market oflegal services. What spheres, service delivery services can become rivals to law firms?]. Retrieved from: http://officium.law/pdf/\%D0\%A3\%D0\%AE_\%D0\%BC\%D0\%B0\%D0\%B9_2016. pdf (accessed September 5, 2018) (in Ukrainian)

Bot-providnyk [Bot-conductor] (2016). Ukrainskyi yuryst, 5. Retrieved from: http://jurist.ua/?article/1074 (accessed September 5, 2018) (in Ukrainian)

Yaremenko, R. (2016). Kolosalnyi potentsial [Colossal potential]. Ukrainskyi yuryst, 5. Retrieved from: http://jurist.ua/?article/1074/ (accessed September 5, 2018) (in Ukrainian)

Krasilnikova, Yu. (2017). Bot-yurist DoNotPay osvoil 1000 otraslei prava [Bot-lawyer DoNotPay mastered 1000 branches of law]. Retrieved from: https://hightech.fm/2017/07/12/donotpay (accessed September 5, 2018) (in Russian)

Haazkyi instytut innovatsii u pravi provede konkurs sered yurydychnykh startapiv dlia pokrashchennia dostupu do pravosuddia v Ukraini [The Hague Institute of Innovation in Law will hold a competition among legal startups to improve access to justice in Ukraine]. Retrieved from: http://centernews.com.ua/?p=14593 (accessed September 5, 2018) (in Ukrainian)

Chesbrough, H. (2007). Otkrytye innovatsii. Sozdanie pribylnykh tekhnologii [Open innovation. Creating profitable technologies]. M.: Pokolenie, 336 p. (in Russian) 
Howe, J. (2012). Kraudsorsing. Kollektivnyi razum kak instrument razvitiia biznesa [Crowdsourcing. Collective intelligence as a tool for business development]. Moscow: Alpina Publisher, 288 p. (in Russian)

Boiko-Boichuk, L. V. (2009). Poniattia "sotsialna innovatsiia": typy vyznachen, pryklady zastosuvannia [The concept of "social innovation": types of definitions, examples of application]. Nauka ta innovatsii, 5(3), 94-99. (in Ukrainian)

Nasadyuk A. (2016). Sotsialnyi paket. Kakie initsiativy pro bono podderzhivaiut yurfirmy i pochemu [Social Package. What pro bono initiatives are supported by law firms and why]. Yuridicheskaia praktika, 39. Retrieved from: http://pravo.ua/article.php?id=100114037 (accessed September 5, 2018) (in Russian).

Pro bono: sekret uspekha yuridicheskoi kompanii [Pro bono: The secret of success of a law firm]. Retrieved from: http://jurliga.ligazakon.ua/news/2013/9/10/97411.htm (accessed September 5, 2018) (in Russian)

Rabota ne pro bono [Non-pro bono work] (2015). Yuridicheskaia praktika, 30-31. Retrieved from: http://pravo.ua/ article.php?id=100111580 (Accessed September 5, 2018) (in Russian) 